\title{
Italian fascist modernisation and colonial landscape in Albania 1925-1943
}

\section{Modernização fascista italiana e paisagem colonial na Albânia 1925-1943}

\author{
Enriketa Pandelejmoni, \\ University of Tirana, Albânia
}

\begin{abstract}
Environmental history and landscape transformations vis-à-vis agricultural modernization policies such as the reclaiming of land hardly features in studies on the Italian fascist annexation of Albania. This paper focuses on the main features of Italian economic and landscape efforts in Albania during the fascist years through a general overview of the Italian period with respect to economic and land reclamation works, and an exploration of Italys colonial policies in the modernization and regeneration of Albanian landscape. Its scope includes Italys interwar interventionist efforts in Albania in economy and land reclamation, but not the substantial literature on Italian contribution to the transformation of Albanian urban landscapes during the interwar period. The urban planning of Albania by Italian architects, engineers, and urbanists that developed from 1920 to 1939 has been dealt with extensively in scholarship regarding Albania.
\end{abstract}

Keywords-Albania; Fascism; Landscape; Reclamation; Colonialism; Italy; Società Littorio.

Resumo-A história ambiental e as transformações da paisagem face às políticas de modernização agrícola, tais como a recuperação de terras, dificilmente figuram nos estudos sobre a anexação fascista italiana da Albânia. Este texto centra-se nas principais características dos esforços económicos e paisagísticos italianos na Albânia durante os anos fascistas através de uma visão geral do "período italiano" no que diz respeito às obras de recuperação económica e fundiária, e explora as políticas coloniais italianas na modernização e regeneração da paisagem albanesa. O seu âmbito inclui os esforços intervencionistas italianos entre guerras na Albânia em matéria de economia e recuperação de terras, mas não a literatura substancial sobre a contribuição italiana para a transformação das paisagens urbanas albanesas durante o período entre guerras. O planeamento urbano da Albânia por arquitectos, engenheiros e urbanistas italianos que se desenvolveu de 1920 a 1939 tem sido amplamente abordado em estudos académicos relativos à Albânia.

Palavras-Chave-Albânia; Fascismo; Paisagem; Reclamação; Colonialismo; Itália; Società Littorio.

Submitted-12-08-2021. Accepted-18-11-2021.

- Enriketa Pandelejmoni

E-mail: enriketa.papa@unitir.edu.al
"Non vi è dubbio che se potremo lavorare in pace entro alcuni anni saremo in possesso della più ricca regione d'Italia/There is no doubt that if we can work in peace, within a few years we shall possess the richest region of Italy. " (Ciano, Diario, August $\left.19^{\text {th }}, 1939\right)$ 


\section{Introduction}

$\mathrm{T}$ HE conquest of Albania by fascist Italy on April 7, 1939 was the culmination of the longer insistence on political and economic domination of Italy upon Albania. During 1925-1943, within the framework of several bilateral agreements the presence of Italian economic-financial investments in Albania grow heavenly. Italian investments were related to the modernization of Albania and establishment of joint ItalianAlbanian companies. The economic and political investment of Italy was wrapped in a colonial "civilizing" facet, that culminated with the military occupation of Albania, turning the country into a hybrid form of Italian colonial domination.

This paper focuses on the main features of Italian economic and landscape modernisation efforts in Albania during the fascist years through a general overview of the formal and informal Italian rule, known in Albania as "koha e Italisë" (Italian period), as a reminiscence of the period from 19251943, when most of the economic, agrarian and building enterprise in Albania was undertaken by Italian companies. The paper will explore first the "Italian period" with respect to Italy's colonial policies toward Albania and concrete initiatives of modernization and regeneration of Albanian rural landscape. My aim is to investigate the Italian colonialism in Albania, specifically in the context of agricultural modernization programs such as the reclamation of land. My interest lays in analysing how Italian agrarian interventionism in the Albanian landscape was shaped by a "civilisation mission". Secondly, using archival research, I will expand my analysis particularly on the district of Kavaja (1939-1943), as a case-study for understanding the importance that Fascist Italy put on economic valorisation of its imperial communities. Borrowing Rodogno's insights (Rodogno 2014) on Italian 'spazio vitale' in the context of rural Albania, I will try to expand my overview on Kavaja district, previously owned by the Albanian state and some local landowners, and turned three months after the occupation of Albania, in summer 1939, over to a private Italian company. It served as a model for constructing a Fascist civilizational core with trustworthy Italian colonist and Albanian settlers, whose duty was to valorise the use of landscape and undertake vast land reclamation.

\section{Italian political and economic ex- pansionism in Albania prior to annexa- tion}

Italian colonial ambitions over Albanian territories began already during the Ottoman rule, in parallel with Italian expansionist policy in North Africa. The earliest Italian efforts (1910-1911) in achieving economic aims in Albanian provinces of the Ottoman Empire included projects on the exploitation of forests in the northern region of Mirdita, land reclamations, bridge construction, and the building of a railway line across the Balkans to the Adriatic coast. Such projects did not materialize due to the outbreak of the war in Libya (Lampe and Jackson 1982, 208; Bosworth 1975, 583-4). Albania proclaimed its independence in 1912, and Italian diplomacy played a crucial role over the recognition of Albanian independence and supporting the new constitutional principality of Albania under a German Prince (Duka 2007, 34-36). After entering First World War in 1915 Italy agreed to divide up Albania between Balkan countries, leaving a small autonomous state in the central regions under its mandate. (Vickers 2001, 87; Duka 2007, 89). Following the end of WWI (1918-1920), Italy's ambitions in Albania became clearer in the town of Vlora which became the centre of the Italian political protectorate over Albania and plans were even being discussed for moving Italian peasants from the region of Emilia with the double purpose of easing the demographic weight in Italy and bringing civilization (Bego 2017, 108-9). Italians were opposed by a local insurrection supported by the Albanian government and were forced to leave Vlora's possessions in early September 1920, but obtained recognition from the League of Nations to defend Albania's borders, granting thus the right of a de facto protectorate upon Albania.

In the years to follow the relations between Italy and Albania improved and both countries moved swiftly in reaching agreements on trade and infrastructure by giving Italian companies privileges in oil and mineral resources' exploitations, in the state-bank sector, public works, 
forests concessions and in regulating the migration of workers with the Government of Ahmet Zog (1925) who became $1928 \mathrm{King}$ Zog I of Albanians (Pastorelli 1966, 52). The 1925 loan agreement established the Società per lo Sviluppo Economico dell'Albania (SVEA - Society for the Economic Development of Albania), which was responsible for the management of the Italian loans to Albania. Throughout the late 20'ies and 30'ies SVEA loans were used in expanding the Italian investments into Albania economy by awarding mostly to Italian companies' public works as construction of roads, railroads, ports, public building and land reclamation and swamp draining projects. SVEA loans were used to create a political and economic dependency of Albania towards Italy, which became extremely vulnerable to Italian political pressure. Italian advisors were hired in the Albanian public administration, as in the military, education, economic sectors (Mëhilli 2017, 24; Pula 2008, 575).

In 1925 with a SVEA loan was established the Albanian National Bank, which issued the Albanian currency Lek (ALL), and functioned as well as Albania's state treasury (Roselli 2006, 30-34; Fishta 1971, 4). Plans were made for the construction of new roads and bridges along the TiranaDurrës, Shkodër-Elbasan, and Durrës-Vlora lines. Of particular importance was the construction of public and military buildings, villas, royal palaces, and ministerial offices in the capital Tirana, where work was regulated in accordance with the plan designed by Armando Brasini and Florestano di Fausto (Menghini 2013, 43). Engineer Luigi Luiggi was responsible for the Port of Durrës project and drafting the swamp reclamation plan over an area of about $3 \mathrm{~km}^{2}$ around Durrës for the eradication of malaria. This plan aimed to (1) transform "the dead swamp into a living lagoon" by building a system of canals consisting of a main canal connected to secondary canals to allow the entering of salty sea water into the lagoon, thus preventing the reproduction of mosquitoes; and (2) to fill part of the marshes with materials excavated from streams and the dredging of the port, thereby transforming the marshy lands into "perfectly reclaimed and cultivable land that will generate great agricultural income and become a source of wealth for farmers and the country"
(Godoli, 2013, 56). Land reclamation and swamp draining works were part of Italy's 1930s efforts to enable the future settlement of Italians and the establishment of several experimental agricultural farms alongside Albania's western lowlands of Durrës, Shijak, Kavajë, and Vlorë (Arkivi Qendror Shtetëror/National Central Archive - later cited as AQSH 1943, Fondi (F.). 462, Dosja (D.) 4. Viti (V.). 1931 Fleta (F). 1-6).

According to Fischer, SVEA money gave the impression that the Italians were using it to carry out a series of works in the interest of Albanians, but roads and bridges were built for Italian military purposes, mainly towards the borders with Greece and Yugoslavia. The port of Durrës was expanded to the extent that upon its completion ships larger than usual merchant ships could be anchored (Fischer 1984, 104). Pula instead considers that Italy made the most significant inroads into Albanian social and political life. Italy's use of Albanian state apparatus, to introduce fascist forms of social organisation, meant that by 1939 annexation, Albania was primed for fully fledged fascism (Pula 2008, 575).

Landscape investments and agrarian investments and land reclamation were carried out by "Ente Italiano Attività Agraria" (EIAA-Italian Agency for Agricultural Activities), which was the largest company operating in the agrarian sector, with the aim of developing experimental farms and settling Italian colonists. It obtained a concession of 3,000 hectares of land in the Shijak plain in 1926, and was granted the right to purchase and export agrarian products directly from Albanian producers and cooperatives (Trani 2007, 30).

It is possible to get a sense of the kind of reclamation project Italians had planned by analysing a model of contract between farmers and EIAA that is preserved in archival folders of Central Archive in Tirana. EIAA drafted a contract for sharecropping in 1931 that would to be valid for 7 years. The contract was signed in Rome by the EIAA and the Office for Internal Migration and the National Confederation of Fascist Unions (AQSH, F. 462, V. 1931, D. 4, Fl, 115). According to this contract, the settler (called mezzadro/sharecropper) or colono was the head of an entire farmhouse household, which included the settler's relatives and kin. Family units would 
migrate to Albania only to settle in the EIAA's farm where adult men between 18 and 65 who were able to work the land were called work units, while boys from 15-17 and women up to 65 years old and suitable for work were considered half units. The entire family was committed to work the land and to share their products and profits with EIAA. EIAA was responsible for land reclamation works, plantations of vines, orchards, and olive groves, for the chemical fertilization of the new plantations, the excavation of new places, as well as the execution and maintenance of new embankments. The settler was obliged to cultivate the land as an expert farmer with the "diligence of a good family man", in conformity with directives issued by the company management, in order to obtain the right to participate in the division of products in return for the work performed. He was required to dedicate his own work and that of his family members to the farm, to take care of livestock, and to work on individual crops, as well as the harvest and conservation of the products up to the moment of their division. The settler had to take care of the orderliness of the house, the stable and related works, as well to supervise the farm to prevent any damage and usurpation. He could keep for his own back yard a poultry farm of 50 heads, 2 pigs, and 2 milk goats. The settler was granted a small plot of land in the vicinity of the farmhouse for planting a vegetable garden for family use. Everything produced therein remained the sole responsibility of the settler. The company gave each farmhouse a premium of Lire 2000 maximum and Lire 1000 minimum as compensation for food for the first year (AQSH, F. 462, V. 1931, D. 4, Fl, 4-14).

After almost a decade from the inception of EIAA, in May 1935 the Italian Minister in Tirana Mario Indelli proposed to the Albanian government the settlement of Italian peasant labourers near Shijak and Durrës, where EIAA had its concession along with a package of several loan agreements (Pearson 2004, 370). On March $19^{\text {th }}$ 1936 the Berati-Indelli Agreements was signed in Tirana which foresaw: (a) the payments by the Italian government to Albania in liquidation of the 10-year loan of 1931 over a two-year period; (b) the funding of the Albanian state budget deficit; (c) the capital refinancing of the Albanian
Agricultural Bank through an agricultural loan over a three-year period; (d) a loan for the tobacco monopoly over a two-year period and two loans for the port at Durrës were agreed upon (Roselli 2006, 61, Archive of the Ministry of Foreign Affairs - AMPJ 1936, D. 13). Tomes notes that these agreements (13 in total) "represented Albania's capitulation to Italian fascism. Albania became an Italian colony. Its chief port Durrës threatened to become another Massawa, the jumping off place for the next Italian imperial adventure" (Tomes 2003, 180).

Following the agreement, Italy announced in April 1936 that "300.000 Italian colonist would settle in Albania shortly", while denying that concessions were granted for Italian colonization (Pearson 2004, 379). In August 1937 Count Ciano envisaged his colonial vision for Albania in his Diary:

"I have persuaded the

Duce to give 60 million to Albania over the next four years for works of various kinds... We must create stable centres of Italian influence there. Who knows what the future may have in store! We must be ready to seize the opportunities that will present themselves. We are not going to withdraw this time, as we did in 1920. In the south we have absorbed several hundred thousand Albanians. Why shouldn't the same thing happen on the other side of the entrance to the Adriatic?" (Ciano 2006, 28)

Meanwhile EIAA General Director sent a letter to the Albanian Undersecretary of the Ministry of Economy Terenc Toçi in 1937, in which he asked to accommodate in its new farm of Rushkull new Italian settlers as the Albanian peasant workers "were not motivated to work". But, in order to do so, the Albanian Agrarian Law represented an obstacle, banning the existence of property with an unproductive area of more than 40 hectares and nationalized the surplus of each property. The expropriated parts were to be redistributed to citizens with no land, or whose land did not meet their family's needs (Roselli 2006, 128). EIAA, land reclamation works could not be carried out by poor rural families, they required a certain capital investment which the society would issue only if the Ministry of Economy would displace Albanian peasant labourers and accom- 
modate Italian peasants in Rrushkull as it had done with the concession in Shijak. EIAA claimed that its "experiment at Rushkull is unlikely to succeed unless one wants to tackle the problem of replacing current farmers with more suitable and well-intentioned Italian colonial families" (AQSH, F. 462, V. 1937, D. 4, Fl. 1-3). EIAA reminded Toçi of the work undertaken for the modernisation and development of agrarian lands in its own territories. 1926-1937, EIAA invested 25 million Liras for the creation and development of modern agrarian farms in Shijak, and sought to extend its territories to create a farm in Rrushkull, which would become the first modern agrarian farm in Albania (AQSH, F. 462, V. 1937, D. 4, Fl. 4).

Nevertheless, until 1939 land reclamation and regeneration of Albanian rural landscape were realised at a slow pace. The land distribution with most of land in the hands of few landowners was an obstacle in expanding the projects for agrarian modernization. EIAA's project was extended to a few areas, mainly in Rrushkull and Shijak (AQSH, F. 462, V. 1943, D. 28, Fl. 2-6).

\section{Annexation and colonial endeavour}

On Good Friday, April $7^{\text {th }} 1939$ Italian troops landed on the Albanian coast without any formal declaration of war. Italian bombers over the Albanian sky scattered leaflets in Albanian with messages like, "Italian troops who have been your friends throughout centuries have often demonstrated that friendship to you" (Pearson 2004, 443). The occupation took place in two days, whilst King Zog, his wife, and their 2 days old infant fled to Greece.

On 12 April 1939, the National Constituent Assembly proclaimed the abrogation of the political regime theretofore in force, as well as the abrogation of the constitution of 1928; created a puppet government vested with full powers; and expressed the desire for the creation of a union between Italy and Albania, offering the Crown of Albania to the King of Italy in the form of a personal union. The royal decree of 18 April 1939 established an Under Secretariat for Albanian Affairs in the Italian Ministry of Foreign Affairs headed by Zenone Benini (Roselli 2006, 99). This was soon followed by the 3 June treaty according to which Italy would manage the foreign affairs of Albania and represent it abroad. This hybrid union was mainly implemented by the newly created office of the Deputy General of Albania (Luogotenente Generale), by the Albanian Fascist Party (AFP), and by the assignment of permanent Italian counsellors in Albanian ministries. The Viceroy, who represented the exiled King, held the right of sovereignty. While Italy controlled the Albanian government through its appointive powers, the government was controlled from within by the permanent Italian counsellors, who were active in every ministry (Papa-Pandelejmoni 2014, 435).

Mussolini promised the Albanian people that he and fascist Italy would bring Albania justice, order and prosperity, as he was known for keeping his word! (Straneo 1940, 7; Gurakuqi 2018, 82). An agreement had been reached previously about the fusion of the two armies, the fascist organizations, and the customs union, as well the equivalence of the Albanian Lek to the Italian Lira.

The union between the two countries in reality it can be seen as a colonial dependency within the Imperial Community, as the two countries shared the head of state, the fascist political regime and diplomatic representation, and had unified their customs and armies (Mai 2003, 84). Albanian citizens in Italy and Italian citizens in Albania were entitled to all civil and political rights that they enjoyed in their respective countries (Ambrosini 1940, 64). Albania was ranked as a privileged Italian colony in comparison to African colonies subordinated to Rome, although granted the fact, that from a formal, legal point of view, the union of Italy and Albania was bound by international law, and was an agreement between sovereign bodies. Albania formally maintained territory, people and sovereignty, but substantively it emerged immediately that it was subordinate to Italy (Villari 2007, 160).

Mussolini made efforts at not identifying Albania as a colony and insisted that Albania's independence was being preserved, although would be Fascistisised and Italianised (Pula 2008, 576). Italy's Mediterranean expansion was portrayed as the natural continuation of ancient Rome's "civilizing mission" (Ben-Ghiat, Fuller 2005, 2). The bilateral connection between Italy and Alba- 
nia was justified within the Italian-Mediterranean 'spazio vitale', a kind of equivalent to the German's Lebensraum. The spazio vitale according to Rodogno was organised hierarchically on racial principles, at the lowest level consisted of the indigenous peoples of Africa, and at the apex stood the Italian imperial race (Rodogno 2005, $322 ; 2006,48-52)$. Within the vital space Rome would impose the 'new order' (ordine nuovo) and organize a community both for peoples of which it was made up and for those other peoples, which, though less civilized, would nevertheless grow and develop, like those who previously belonged to the Roman Empire. (Rodogno 2006, 48). Within the Imperial community fascist revolution would create the new man accomplishing Mussolini's revolutionary endeavor to create a new world. The new Italian men would illuminate the world with their art, educate it with their knowledge, and give robust structure to the new territories with their administrative technique and ability, with their enterprise and organization of trade (Rodogno 2005, 321-323). Hence fascist rhetoric propagated that the Italian government spent millions of liras over the past years to help Albania in every way. The country was presented as exotic and attractive, the "Oriente sotto casa", a fascinating country like a bazaar, and at the same time its considerable natural resources were not even exploited, waiting instead for the older brother, Italy, to put them to use (della Rocca 2001, 215). The reclaiming of Rome's glory through imperial conquest and the 'perpetuation and expansion of Italianness [in the world]' through a parallel work of 'spiritual penetration' constitutes a central element of fascist ideology (Ben-Ghiat 2006, 385). That's why in order to legitimize this imperialist project Italian academics and politicians downplayed Albania's cultural, social, and political cohesiveness and its viability as an autonomous national entity, legitimising Italy's entitlement as Albania's natural protector, while unearthing its resources (Mai 2010, 83). The fascist axioma was progress through Fascistisation.

The Albanian historian Dëzhgiu points out the importance of the strategic fascist spazio vitale in the Balkans, where Italy sought to create a "continental autarchy" by controlling the region's wealth. Through vital space narrative Italy sought to control the wealth of the Balkans for its war economy and the creation of the "Imperial Community". Albania with its rich natural resources would be useful for the autarkic Italian economy. It was a country with many great economic opportunities, and its agricultural areas were considered of a great development potential. At the same time, Albania was important to Italy because of its geographic position, serving as an economic bridge to Eastern Balkans (Dëzhgiu 2005, 146). Pula considers the Italian rule in Albania 19391943 as a colonial form of domination. Italy's expansion in Albania is a feature of colonialism, as it was accompanied by the settlement of acquired lands by colonists. Italy considered Albania to be a territory open to Italian settlement. Further Italy dominated largely in controlling Albania with its heavy Italian military presence; the political sphere by establishing an institutional structure that gave ultimate political power to Rome; and economy through the control of state finances, the flow of capital, and the exploitation of labour and natural resources (Pula 2008, 577).

To the core of the Fascist imperialism stands the idea of 'valorizzazione' (valorisation), by which was meant an economic mission to civilise the economies of the countries that would belong to Rome. The 1939 valorisation endeavour in Albania was associated with an extensive policy of both public works and integral reclamation (Rodogno 2005, 319). Economic, urban, industrial and agricultural programs were drawn up aiming to civilised and modernize Albania. In May 1939 Jacomoni met in Rome with Benini, and other high officials to discuss concrete economic and technical plans for Albania (Gurakuqi 2018, 100). In a study report submitted to Mussolini in October 1939, Benini outlined Albania's natural and economic resources, underlining the importance of accomplishing large land reclamation works in Durrës, Shijak, Tiranë, Vlorë, and Fier by the end of 1941 (Amendola 1939, 23; Sakja 2016, 174; 34; Milo 2014, 63). While the reclamation of the Durrës swamp was in progress, which completion was scheduled for 1941. Reclamation works had been carried out in Myzeqe, and a large experiment on land reclamation was started in the Kavaja (Figure 1). It was expected that complete regeneration of rural landscape would affected 
over 200,000 hectares of land (Sakja 2016, 176). Benini's optimistic report hoped that extensive investment in Albania would bring both economic and political benefits for the next 10 years.

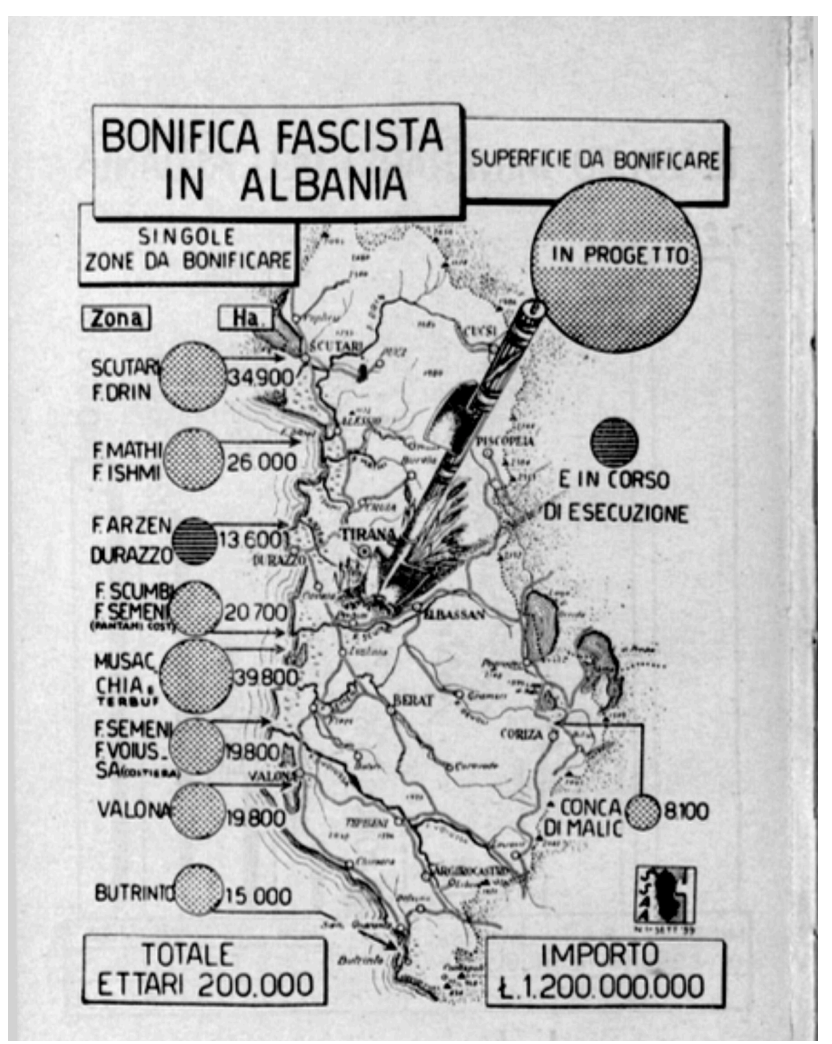

Figure 1: Fascist reclamation plans in Albania proposed by Benini (Annuario del Regno di Albania, 1940, 110).

Fascist redemption of nature, man and society were the core of the reclamation and valorization that Italians aimed in accomplishing in Albania. The agrarian-human-cultural reclamation scheme was expressed in the redeeming efforts on landscape and people. Reclamation was essential in the improving the physical, economic and cultural condition of the country by transforming landscape and people at the same. The new Fascist state in Albania would take an engineering role in imposing to people and landscape its regenerative vision of a civilized and developed country. This transformative vision was reflected in many articles published in the newspaper Fashizmi, the official newspaper of AFP and Ekonomia Kombëtare (National Economy), the official newspaper of the Ministry of Economy. In 1940 article of Ekonomia Kombëtare entitled "The Fascist regime and the Albanian peasant" the focus was put on the goal to improve the rural environment and the Albanian race:

"To improve the Albanian village and farmers living conditions a huge reclamation work is required. The reclamation work in Albania is a difficult task, but even more difficult is the regeneration of the Albanian village, and the pulling out of villagers from the misery. In order to be aware of his important role and his mission in the society, the peasant (katundari), must be rescued from the plagues and diseases to enter into the human civilized world. He needs to be redeemed from damnation of past landowning beys; to be aware about his role and mission in the society, but particularly he has to be devoted and love the village and his land, in which he has tied himself with boundless bond. What Fascism is about to accomplish in Albanian lands is one of the largest crusades, which will be mentioned in history. Is not only about improving the economic conditions, but is a matter of rescuing a nation, a whole race."

The transformation of nature into a modern landscape and of peasant into a Fascist 'new man' were the goals of the environmental reclamation policy. Fascism built its own blood and soil narrative in which the racial quality of people was embedded in the national landscape, a result of both natural and racial/historical forces (Armier 2011, 14). Fascist integral reclamation was the way out from misery and corruption as it has occurred in the Italian soil.

"The redemption of Albanian nation and its people would only come from Fascism and duce. Soon the same transformation that have been visible in Pontine Marshes or Sicily would be real in Albania too!" (Ekonomia Kombëtare 1940, 22)

Albanian historians assume that Italy with its economic policy and exploitation of the country's natural resources practically turned Albania from mid 20-ies into its colony. The fascist strategy of Rome in its essence was not only the creation of a military base in Albania for further expansion into the Balkans, but also the use of Albania's natural resources and economic potentials (Milo 2014, 61). Italian officials planned to make use of the potentials that Albanian rural landscape presented 
to bring "extinguished" Italian settlers in and to overcome centuries-old agrarian backwardness (Dëzhgiu 2005, 148-49). The need to increase the production capacity in Albania made the Italian occupation authorities realize the need for more Italian labourers in Albania. That was the reason why the Italians requested that large tracts of land belonging to Italian companies be given to Italian citizens. This would ensure the accommodation of Italian settlers in Albania, who would bring about the disruption of the political status quo of local Albanian interests in favour of Italian interests (Gurakuqi 2018, 147). Hence in Albania an Italian colonial system of domination was built up. Italy maintained a large military presence, established an institutional structure that gave ultimate political power to Rome, maintained metropolitan domination over the economic sphere and opened the country to Italian settlers (Pula 2008, 577578). Rome established in Albania a kind of a protectorate order based on cultural diffusion and not on the Nazi racial order that Germans placed in Europe. The cultural circles propagated the Albanian-Italian bond. Italy's pursuit in Albania embedded within the colonial project, was characterized by deeper economic integration and an intricate system of institutions aimed at binding to Rome (Mëhilli 2017, 24). Saying that, Italian colonisation project went along Mussolini's demographic view. Mussolini defined the demographic problem as "an aspect of public health", believing that the population strength was the basis of the political, economic, and moral power of the state. (Podestà 2012, 255). The reclamation of land and the repopulation of countryside areas in Italy and in its colonies by peasants, not contaminated by urban hedonism, would have maintained the characteristics of strength, vitality, and sobriety, which represented values of fascist Italy. The demographic colonization would prevent Italy from the consequences of bourgeois degeneration of urbanism: hedonism, consumerism, poor fertility, and pacifism (Podestà 2012, 256). The peasant colonial families would be placed in new rural villages created in Africa and Albania where they would obtain their own farms, tools, and supplies. This is the reason why the organic family unit should have become the basis for migration to the colonies: to preserve and expand the Italian race, culture, and lifestyle (Podestà 2012, 256).

Although Italians had vague ideas about Albania offering Italy territory for settlers, a project for the demographic colonization of Albania drafted by Italian specialists was submitted to Jacomoni on August $1^{\text {st }}$, 1939, to bring up to 2 million Italian settlers to outnumber the local population (Berend 2006, 126). An Italian-Albanian society was established for this settling. Known as Littorio, it was responsible for the agrarian assessment of 10,000 hectares of land in Kavaja area (Gazetta Ufficiale Albanese, October $14^{\text {th }}$ 1939). This colonial program foresaw the accommodation of Italian settlers alongside development of cultural and educational programs. Only through such triple reclamation scheme as Ben Ghiat called it, namely bonifica agricola, bonifica umana, and bonifica culturale could Italy aimed at remaking nature according to an ideal optimum, the purification of culture on a nationalistic basis, and engineering of the 'new Italian men' (Ben Ghiat 2011, 4).

Cultural reclamation imposed the rise of educational programs for both Italians and Albanians. Archaeological excavations were undertaken to find the 'Romanita' of the new territories. Several Italian cultural and cinematographic entities were given the exclusivity for both the creation and management of cinemas, and the distribution of journalistic and documentary films produced by LUCE Institute (Trani 2007, 6970). The fascist lifestyle was propagated in the journals and magazines; the foundation of cultural institutions of various kinds, as Dante Alighieri Society, "Scanderbeg Foundation" spread Italian language, culture and academic life Likewise, Società geografica italiana promoted a study mission to deepen the knowledge of the Albanian territory and population. The Royal Academy of Italy was used as a propaganda tool in appointing several Albanian personalities as its members, and creating a Study Centre for Albania. Scholarships for Albanian scholars and students to research and study in the Italian universities were another tool in increasing Italian influence (Trani 2007, 70-72).

Apart from the urban transformation of the capital centre, Italians built in Tirana a "Pater" village named after the Milanese company of the Swiss engineer Dario Pater producing prefabricated buildings, with 500 homes for Italian fam- 
ilies (Santoianni 2008, 80), composing from the aerial view the DUX. An agricultural enhancement program was started, in which the farms resulting from the integral reclamation were organized. A flat area with fertile land near Tirana was chosen and divided into two zones, where 900 Italian and 2,000 Albanian families were to settle. The houses, arranged in groups, were located at the centre of the farms and formed 6 villages, with a population of 8,000 units spread over nearly 36,000 arable hectares (Santoianni 2008, 80).

\section{The district of Kavaja - as a model for the agricultural colonization of Alba- nia}

On October $8^{\text {th }}$ 1941, Ciano mentioned in his diary a gift that the Albanian government wished to give to the Italian General Ugo Cavallero, the commander of the Italian army in the GrecoItalian War. Ciano noted:

"The Albanian Government's intention to offer to General Cavallero some Albanian soil. At the time I thought that it had to do with the custom and made no objection. But when I learned that the offer was not symbolical, since it had to do with a grant of almost twenty-five hundred acres of land in Fieri, I definitely opposed it. This did not please the interested parties, who are now trying to twist things around with a letter from [Prime Minister] Vërlaci announcing the accomplished fact. But Cavallero is not grateful to me. Quite the contrary. But... when bread is being rationed and the people are hungry it is not the time to announce that Cavallero is celebrating... a present of a few millions" (Ciano 2006, 543)

The Albanian government seemed inclined to generosity in giving land presents to high Italian officials and duce himself. Four months after the occupation, on August $4^{\text {th }} 1939$ the Albanian council of ministers took a decision to donate to Mussolini 10.000 hectares of land between Kavaja and Shkumbin, in gratitude for duce's interest towards Albania and its people. With this donation the Albanian government expressed its respect to duce who planned to spend 2 billion Liras for the development of the country and use this land as he deemed appropriate in the interest of the common good (AQSH F. 161, V. 1939, D. 438, Fl. 33). The decision was followed on the same day by another one, regarding the expropriation of privately owned 4000 hectares in this land donated to duce. The whole land would be under the supervision of the aforementioned Littorio, which for the district of Kavaja established a land transformation and reclamation company, Impresa $d i$ Trasformazione Agraria e Lavori di Bonifica in Albania (ITALBA), for settling of Italian family units and vast land reclamations (AQSH F.161, V. 1939, D. 438, Fl. 26).

Previously the land reclamation and the settling of Italian colonist family units in Albania was proposed in a memorandum to the Albanian government from Rome on July $31^{\text {st }}$ 1939. This memorandum on "Demographic colonisation in Albania - with Italians and Albanians repatriated from abroad" foresaw that Albanian settlers from Kosovo and Italian family units from abroad and from Puglia would be accommodated in the districts between Durrës, river Shkumbin, Peqin, and the Adriatic Sea. Albanian peasants who possessed land in this area would move in other territories or turn into employees (AQSH F. 161, V. 1939, D. 438, Fl. 3-4). The start of the colonisation was set for September $1^{\text {st }}$ and for that the national road Durrës-Peqin needed to be completed urgently. Italians proposed to acquire the management of the "Near-East" American School of Agriculture in Kavaja, by replacing its American personnel with Italian instructors while keeping the Albanian teaching staff. An agricultural experimental station was to be built near the school, which could immediately begin its work with irrigation and forage production, thereby encouraging the transition to intensive cultivation and the enhancement of the livestock throughout Albania (AQSH F. 161, V. 1939, D. 438, Fl. $5)$. Littorio sought influence over the district of Tirana too, which extended to the coast along the Vorë-Shkodër road. The company would try to purchase lands between Ishmi and Mati rivers (ca. 11,000 ha) through direct negotiation with the landowners. In order to start the reclamation works needed to fit the territory for colonization, Littorio urged the government to accelerate the works on the Vorë - Mati Bridge road (AQSH 
F. 161, V. 1939, D. 438, Fl. 7). It demanded to expand its land acquisition with further 2850 hectares of arable land between Durrës-ShijakKavaja. For that it demanded the support of Jacomoni in granting the management of the land, which was partly shared among private landowners (1000 ha), the municipality of Durrës, (600 ha), Red Cross (600 ha), and the remaining 650 ha of the Ministry of Interior (AQSH F. 161, V. 1939, D. 438, Fl. 6).

Littorio was adamant to expand its land colonization across the entire territory to promote the technical and social elevation of Albanian peasants, who would be able to access land ownership through work. Its work would offer new and stable homes to Albanians and Italians repatriated from abroad, as part of the Fascist initiatives for the creation of a "Greater Albania". For this, it sought the Viceroy's permission for educational programs which would accelerate Albanians' progress to the renovating system of fascist Italy. Through land reclamation and sanitary works the company would contribute in eliminating serious causes of mortality such as malaria and the decay of the Albanian race, ensuring a healthier and more fruitful work in the field of production. The company's activity would further contribute to the autonomy of Albanian food production and to economic autarchy, providing support through an intensive culture and irrigation of the territories. Ultimately, Società Littorio would be a tool of the General Lieutenancy for implementing Mussolini's "highest social justice" for the working people, redemption of the land, the men and the race" (AQSH F. 161, V. 1939, D. 438, Fl. 8). Therefore redemption of environment and the economic valorization would impact powerfully the life of the inhabitants and would transform the Albanian landscape. It was believed that environmental factors had an influence upon the new fascist man, who would live in a civilized and modernized rural landscape. As family units became the core of the Fascist colonization, in order to accommodate the colons' family units, it was necessary to create the necessary civic services for the colonists. Hence the constructions of clinics, schools, nurseries, kindergartens as well churches were indispensable and were entrusted to the Catholic priests and nuns (AQSH, F. 195, V.
1940, D. 561. Fl. 3).

Nevertheless, Litorio's colonization program for entire Albania was opposed by Jacomoni and Giovanni Giro, the Inspector general of AFP. Since for both of them this was the first colonizing experience, they did not wish to give the impression of seeking a purely Italian colonization of Albania. Therefore, the company had to arrange the Albanian peasant population living in Kavaja district and treating them equally with the Italian settlers sharing thus equally the farmhouse, farm units, and employment's contractual conditions. They proposed allowing Littorio to operate only in Kavaja and to administer 10.000 hectares of lands that the Albanian government donated to duce, in order to establish ITALBA there. Jacomoni authorized Littorio to start reclamation on stateowned arable land, and only after the government would reached an agreement on land acquisition and compensation with Albanian private owners, the company would start reclamation work on the expropriated plots. The foreseen intensive reclamation work and regeneration of the landscape was better to be implemented on a much smaller area of land, as it would allowed the population living in the district to live and work comfortably. Jacomoni encourage the company to increase the construction's cost for each colonial house from the foreseen Lit. 42,500 each, as in Kavaja "the company must give a sense of certainty that the Roman colonization being carried out there was both economically and politically solid and safe" (AQSH, F. 161, V. 1939, D. 438, Fl. 12-13). Jacomoni wanted the total control over company, he warned ITALBA and Littorio to allow any governmental initiative to interfere, control and orient the company's projects (AQSH, F. 161, V. 1939, D. 438, Fl. 14-15). Meanwhile Giro encouraged the Italian and Albanian settlers to get agrarian loans in order to buy their property within the district, and discouraged the company to transfer to other districts the small Albanian landowners without setting up property rights avoiding social and political consequences (AQSH, F. 161, V. 1939, D. 438, Fl. 23-24).

Littorio and ITALBA concession in the district of Kavaja was composed by the villages: Reth-Kalush, Balaj, Greth, Shelk, Kërcukaj-Gosë, Zhabjak-Zeleshtik, Ukshton, Rreth, Maskaresh, 
Shar-Dushk and Stan i Ri (AQSH, F. 161, V. 1939, D. 438, Fl. 19-21). In November 1939, ITALBA took under its administration another district of 5500 hectares in Fier-Shegan that was donated to duce by the Albanian government (AQSH, F. 161, V. 1939, D. 438, Fl. 27). By 1943 the company accomplished the reclamation only of marshy land in Kavaja and Durrës plain and established there 600 colony units. These lands were given to the company only in the form of concession and any demand on land acquisition was refused by Jacomoni and Giro, who both wanted to avoid any turmoil by Albanian landowners, who were refusing to sell their property to the Italian companies.

The archival sources reveal that many Albanian landowners refuse to obey to valorisation's program. In Rrushkull dissatisfaction had arisen between EIAA and the peasants since September 1939. The villagers complained that the company had occupied part of their lands, blocked the road to their lands, transferred their yards, and made it difficult for them to keep livestock, putting thus pressure on villagers to impose new contractual terms (AQSH F. 252, V. 1939, D. 243. Fl. 79).

Although during 1939-1943 many Albanian peasants agreed to work as employees of Littorio and EIAA, others preferred to work in urban reclamations and construction. The phenomenon of switching from peasant to labor workers was very profitable for them as the salaries were increased and their economic situation improved. Whilst Italian colonists, who abandoned their colonies due to profitable jobs in the cities were threatened with repatriation to Italy (F. 161, V. 1939, D. 454, Fl. 8-12). EIAA and ITALBA demanded additional Italian settlers from Italy to work in their farms in Shijak, and Kavaja, and the return of Italian settlers who were working in cities where they were better paid. (F. 161, V. 1939, D. 454, Fl. 5, 8-12).

1940-1942 Albanian peasants were dissatisfied about the amount of financial obligations they had to pay off back to the companies and to state. The villagers were complaining about expropriations of their lands due to irrigation works carried out by Italian companies. They were unsatisfied about the unpaid work that they were forced to perform in the reclamation works for both
EIAA and ITALBA, which prevented them to work on their own lands. The reclamation work was limiting the access to their properties. The bank short-term loan was another tool that the EIAA used in forcing the villagers to mortgage the land and in case of non-refundable loans to cede it to the company. As the consequence in Kavaja and Shijak peasants rebelled and set fire on the grain products, clashed with gendarmery, and were punished with interment and expulsion due to sabotage (Dëzhgiu 2005, 149-162).

The Italo-Greek war affected the works of EIAA and ITALBA as many villagers from the southeastern areas on the border with Greece moved in the Myzeqe Plain and in Durrës. They settled in the lands, which previously lived Albanian settlers from Kosovo, the latter had left for Kosovo, after the unification of Kosovo with Albania in August 1941 (Dëzhgiu 2005, 155-156). But after 1942 many suffered unemployment, especially in southern Albania due to the dire situation that the war created.

In the end no matter what the Italians did, their reputation among the Albanians suffered. Their outwardly beneficent measures for local economic reconstruction, including the reclamation of land, mortgage, and loan facilities for farmers were perceived by the Albanians as a mere preparation for an extensive Italian colonization. The methods employed by the banks in granting agricultural loans and arranging mortgages seemed to Albanians to be designed to acquire the best lands for eventual distribution to Italian settlers who, thanks to the new constitution, were now able to own land in Albania (Fisher 1999, 95).

The irruption of capitalist economy associated with reclamation, property rights problems and dissatisfaction among Albanian and Italian companies, the limited access and the use of land were shaping the colonial landscape. From the planned 2 million Italian emigrants that were programmed to settle in Albania, after the end of the war, according to the Albanian Ministry of Foreign Affairs in the country were around 27.000 Italians, most of them military and specialized workers (Papa-Pandelejmoni 2017, 131). 


\section{Concluding remarks}

Although a latecomer to the European colonialism, Mussolini adopted its expansionist policy in Albania. In addition to ideological and economic arguments in developing its own expansionist needs through investing in Albania, Italy would at the same time transform the landscape and push the Albanian society towards modern capitalism. Before the Italian occupation of 1939, Mussolini's policy forced Albanian state to make continuous economic concessions and allow the intervention of Italian capital and companies, and settling of Italian colonists. After 1939 Albania became a satellite of Rome, integrated into the imperial Roman community. Mussolini imposed the application of the fascist model on politics and economics. The system of valorization through Italian companies aimed the fascistisation of the society and lifestyle. The integral reclamation model of people, culture and economy was the essence of the fascist narrative through which the civilization of the Albanian society was aimed according to the model that Rome imposed. Precisely economic valorization was a tool that fascist Italy unfolded on the Albanian landscape. Fascist rural modernisation policies and reclamation were seen as a redemption of landscape and people. Albanian landscape had to be redeemed, the reclamation of nature and people had to be accomplished through technical and modernisation of Albanian peasants and the settling of Italian colonists.

Land reclamation and the improvement of the rural environment in the districts of Shijak 19261943) and Kavaja (1939-1943) were the starting point of a series of plans for the economic valorization of the rural landscape in Western low plains, aiming the regeneration of the rural economy, and of the physical and moral conditions of the people. Agrarian economic policies, through the creation of large Italian farms, installation of Italian and Albanian settlers coming from abroad, expropriation of small Albanian owners, agrarian loans, reclamation works would have economic and physical impacts on the landscape and on the people until Italo-Greek war stopped the reclamation programs.

Belonging to the imperial community, economic autarky, rhetoric on the civilization and redemption mission through the colonization and rehabilitation program, the presence of the Italian army, are indicators of the construction in Albania of a hybrid model of Italian colonization rule. Investments in the landscape with the aim of modernizing and transforming the rural environment, faced difficulties due to the fragmentation of properties; complicated contractual relations on concession and ownership; revolts and clashes between villagers and gendarmes and the lastly due to war effects. The desire to transform the Albanian nature according to the fascist reclamation model, created a kind of a hybrid environment, where the Italians were in the role of colonizingcivilizing primacy, striving for the modernization of the landscape and uncivilized people.

The hybridity of the Italian period was characterized even more by the Italianization of the economy and the landscape which notably was embraced till the beginning of Italo-Greek war, and by the financial benefit of Italian investments in the reclamation works. The dichotomy between tradition, with the fragmentation of land ownership, and modernity, with the collectivization of land holdings to be transformed from reclamation programs into modern farms, was another characteristic of relations during the Italian period. 


\section{References}

[1] Ambrosini, Gaspare. 1940. "L'Albania nella Communità Imperiale di Roma". Quaderni dell Instituto Nazionale di Cultura Fascista, 5. Roma.

[2] Amendola, Antonio. 1939. Assimilazione economica dell'Albania. Edizioni Porti d'Italia: Napoli.

[3] Annuario del Regno di Albania 1940. Milano: Casa Editrice Ravagnati.

[4] Bego, Fabio. 2017. "The Vlora conflict from a TransAdriatic Perspective: History, Myth and Ideology". In, Lichnofsky, Claudia; Pandelejmoni, Enriketa; Stojanov, Darko (eds.) Myths and Mythical Space. Conditions and Challenges for History Textbooks in Albana and South- Eastern Europe. Eckert. Die Schriftreihe Vol. 147. Gottingen: VR Unipress.

[5] Ben-Ghiat, Ruth. 2006. "Modernity is just over there". Interventions: International Journal of Postcolonial Studies, 8(3): 380-393.

[6] Berend, T. Ivan. 2006. An Economic History of TwentiethCentury Europe. Cambridge: Cambridge University Press.

[7] Bosworth Richard J. B. 1975. "The Albanian Forests of Signor Giacomo Vismara: A Case Study of Italian Economic Imperialism During the Foreign Ministry of Antonino di San Giuliano". The Historical Journal, 18: 571-586.

[8] Caccamo, Francesco. 2012. "Italy, the Adriatic and the Balkans: From the Great War to the Eve of the Peace Conference". In Wilcox, Vanda, Italy in the Era of the Great War. Leiden, Boston: Brill.

[9] Ciano, Galeazzo. 2006. Diario 1937-1943. Decima edizione. Roma: Rizzoli.

[10] Della Rocca, Morozzo. 2001. "Roma e Tirana, le convergenze parallele". LIMES, 2: 213-226.

[11] Dëzhgiu Muharrem. 2005. Shqipëria nën pushtimin Italian (1939-1943). Tiranë: Akademia e Shkencave e Shqipërisë. Instituti i Historisë.

[12] Duka, Valentina. 2007. Histori e Shqipërisë 1912-2000. Tiranë: Kristalina.

[13] Fischer Bernd. 1984. King Zog and the Struggle for Stability in Albania. New York: Columbia University Press.

[14] Fishta, Iljaz. 1971. Sistemi monetar dhe $i$ kreditit në Shqipëri (1924-1944). Tiranë: Mihal Duri.

[15] Godoli, Ezio. 2012. "Progetti per la SVEA (società per Lo Sviluppo Economico dell'Albania): documenti dagli archivi di Luigi Luiggi e Guido Fiorini". In Godoli, Ezio; Tramonti Ulisse (eds.) Architetti e ingegneri italiani in Albania. Tiranë: Mihal Duri, 55-64. Edifir: Firenze.

[16] Gurakuqi Romeo. 2018. Shqipëria dhe tokat e lirueme 1939-1946. Tiranë: Botimet Jozef.

[17] Lampe, John R. and Jackson, Marvin R. 1982. Balkan Economic History, 1550-1950: From Imperial Borderlands to Developing Nations. Bloomington: Indiana University Press.

[18] Menghini, Anna Bruna. 2013. "La presenza italiana attraverso gli istituti e gli enti per le opera pubbliche". In Calace, Francesca. "Restituiamo la storia". Dagli archivi ai territori. Architettura e modelli urbani nel Mediterraneo orientale, 42-55. Roma: Gangemi Editore.

[19] Mëhilli, Elidor. 2017. From Mao to Stalin. Albania and the Socialist World. London: Cornell University Press.

[20] Milo Paskal. 2014. Shqiptarët në Luftën e Dytë Botërore. Vol. 1. Tiranë: Toena.

[21] Papa-Pandelejmoni, Enriketa. 2014. "Albania during WWII: Mustafa Merlika Kruja's Fascist Collaboration". The European Legacy, 19(4): 433-441.

[22] Papa-Pandelejmoni, Enriketa. 2017. "Il rimpatrio degli italiani e lo stallo nelle relazioni Albania-Italia (1945-1957)". In Paolo Rago (ed.) Una pace necessaria. I rapporti italiano- albanesi nella prima fase della guerra fredda, 127-172. Bari: Editori Laterza.

[23] Pastorelli, Pietro. 1966. "La penetrazione italiana in Albania. Gli accordi economici italo-albanesi del marzo 1925". Rivista di Studi Politici Internazionali, 33(1): 8-60.

[24] Pearson Owen. 2004. Albania and King Zog: Independence, Republic and Monarchy, 1908-1939. London: IB Tauris.

[25] Podesta, Gian Luca. 2011. "Colonists and "Demographic" Colonists. Family and Society in Italian Africa". Annales de démographie historique, 122(2): 205-231.

[26] Podestà, Gian Luca. 2012. "I censimenti nei domini coloniali come fonte per la storia sociale". In Alfani, Guido et al. 2012 (eds.) I censimenti nell'Italia unita. Le fonti di stato della popolazione tra il XIX e il XXI secolo. In Annali di statistika, Anno 142, Serie XII - Vol. 2, 253-274. Roma: Istituto nazionale di statistica.

[27] Pula, Besnik. 2008. "Becoming Citizens of Empire: Albanian Nationalism and Fascist Empire, 1939-1943". Theory and Society 8, 37(6): 567-596.

[28] Rodogno, Davide. 2005. "Progetti e finalità delle politiche fasciste d'occupazione". Contemporanea, 8(2): 317-323.

[29] Rodogno, Davide. 2006. Fascism's European Empire: Italian Occupation during the Second World War. Cambridge: Cambridge University Press.

[30] Roselli Alessandro. 2006. Italy and Albania: Financial Relations in the Fascist Period. London-New York: I.B.Tauris.

[31] Ruth Ben-Ghiat and Mia Fuller (ed). 2005. Italian Colonialism. New York: Palgrave Macmillan.

[32] Santoianni Vittorio. 2008. "Il Razionalismo nelle colonie italiane 1928-1943. La "nuova architettura" delle Terre d'Oltremare". Ph.D. Thesis, Universita degli Studi di Napoli "Federico II".

[33] Sakja, Rovena. 2016. "Così vicina, così lontana: visioni fasciste dello sviluppo dell'Albania negli anni quaranta". Nuovi annali della scuola speciale per archivisti e bibliotecari, 169190. Firenze; Leo S. Olschki Editore.

[34] Straneo, Carlo Alberto. 1940. "L'Albania nel Impero". RIVISTA D'ALBANIA, 1(1): 5-9.

[35] Tomes Jason. 2003. King Zig self-made Monarch of Albania. Stroud: Sutton Publishing.

[36] Trani Silvia. 2007. L'Unione fra l'Albania e l'Italia. Censimento delle fonti (1939-1945) conservate negli archivi pubblici e privati di Roma. Roma.

[37] Vickers, Miranda. 2001. The Albanians, A Modern History. London, New York: I.B. Tauris Publshers.

[38] Villari, Giovanni. 2007. "A Failed Experiment: The Exportation of Fascism to Albania". Modern Italy, 2(2): 157-171.

\section{Archives in Tirana}

Arkivi Qëndror Shtetëror/Central State Archive (AQSH), Fondi 161, 195, 252, 462.

Arkivi i Ministrisë së Punëve të Jashtme V. 1936.

\section{Newspapers}

Ekonomia Kombëtare 1940 


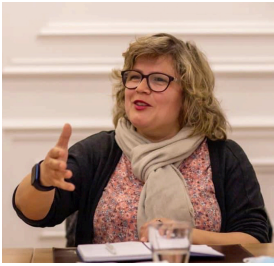

Enriketa Pandelejmoni (PAPA) is an associate professor of history at the Department of History, University of Tirana. She has a $\mathrm{PhD}$ in Contemporary European and Southeast European History from the University of Graz, Austria. Her main research interests include Albanian contemporary history and memory studies. She is the author of the monography, Shkodra. Family and Urban Life 1918-1939 (LitVerlag 2019), and co-author of the edited volumes, History of Communism in Albania through the archives (Tirana 2020), Myths and Mythical Spaces. Conditions and Challenges for History Textbooks in Albania and South-Eastern Europe (Göttingen 2018); The Call for Freedom. Studies on Totalitarianism and Transition in Albania (Tirana 2016) and Albania. Family, Society and Culture in the 20th Century (Münster 2012). She has published in several academic journals and actually is working on Albanian-Italian Political gridlock after WWII. 